\title{
Perbandingan Pertumbuhan Jamur Aspergillus flavus Pada Media PDA (Potato Dextrose Agar ) dan Media Alternatif dari Singkong (Manihot esculenta Crantz)
}

\author{
Artha Octavia ${ }^{1}$, Sri Wantini ${ }^{2}$ \\ ${ }^{1}$ Program Studi D IV Analis Kesehatan Politeknik Kesehatan Tanjungkarang \\ ${ }^{2}$ Jurusan Analis Kesehatan Politeknik Kesehatan Tanjungkarang
}

\begin{abstract}
Abstrak
Potato Dextrose Agar (PDA) merupakan salah satu media yang digunakan untuk pertumbuhan jamur Aspergillus flavus. Media PDA dibuat pabrik dalam bentuk sediaan siap pakai, harganya mahal, higroskopis, dan hanya diperoleh pada tempat tertentu. Melimpahnya sumber alam seperti singkong (Manihot esculenta Crantz), dapat digunakan sebagai media alternatif pertumbuhan mikroorganisme. Dilakukan modifikasi media pertumbuhan jamur Aspergillus flavus menggunakan air rebusan singkong sebagai komposisi utama pengganti karbohidrat dari kentang. Tujuan penelitian untuk mengetahui perbandingan pertumbuhan jamur Aspergillus flavus pada media PDA dan media alternatif dari singkong. Penelitian ini merupakan penelitian eksperimen dengan cara menginokulasikan Aspergillus flavus dengan metode single dot. Pengamatan dilakukan selama tujuh hari secara makroskopis dengan mengukur diameter koloni jamur menggunakan jangka sorong dalam satuan mm serta dilakukan uji penegasan secara mikroskopis. Hasil penelitian menunjukan bahwa rata-rata pertumbuhan diameter koloni pada media PDA adalah 30,911 mm dengan standar deviasi 15,335 mm, sedangkan untuk media singkong rata-rata diameter koloninya adalah 34,592 mm dengan standar deviasi $15,219 \mathrm{~mm}$. Hasil uji statistik didapatkan nilai $\mathrm{p}=0,690>0,05$, artinya bahwa tidak ada perbedaan antara rata-rata diamater koloni pertumbuhan Aspergillus flavus pada media PDA dan media singkong. Dapat disimpulkan bahwa media singkong merupakan media alternatif yang cukup optimal sebagai pengganti media PDA instan.
\end{abstract}

Kata kunci: Jamur Aspergillus flavus, Potato Dextrose Agar, Manihot esculenta Crantz.)

\section{Comparison of Aspergillus flavus Fungus Growth In PDA Media (Potato Dextrose Agar) and Alternative Media from Cassava (Manihot esculenta Crantz)}

\begin{abstract}
Potato Dextrose Agar (PDA) is one of the medium used for growth of Aspergillus flavus fungus. PDA media are manufactured in ready-to-use dosage forms, they are expensive, hygroscopic, and are only available in certain places. The abundance of natural resources such as cassava (Manihot esculenta Crantz), can be used as an alternative medium for the growth of microorganisms. Conducted media modification of growth of Aspergillus flavus fungus using cassava boiling water as the main composition of carbohydrate replacement from potatoes. The purpose of this research is to know the comparison of Aspergillus flavus fungus growth on PDA media and alternative media from cassava. This research is an experimental research by way of inoculating Aspergillus flavus with single dot method. Observations were made for seven days macroscopically by measuring the diameter of fungal colonies using the sliding range in $\mathrm{mm}$ and microscopic assay testing. The results showed that the average growth of colony diameter on PDA media was $30.911 \mathrm{~mm}$ with a standard deviation of $15.335 \mathrm{~mm}$, while for cassava media the average colony diameter was $34.592 \mathrm{~mm}$ with a standard deviation of $15.219 \mathrm{~mm}$. The result of statistical test obtained $p$ value $=0.690>0,05$, meaning that there is no difference between mean diameter of Aspergillus flavus growth colony on PDA media and cassava media. It can be concluded that cassava media is an alternative media that is optimal enough as a substitute for instant PDA media.
\end{abstract}

Keywords: Aspergillus flavus mushroom, Potato Dextrose Agar, Manihot esculenta crantz.

Korespondensi : Sri Wantini, Jurusan Analis Kesehatan Politeknik Kesehatan Tanjungkarang, Jl. SoekarnoHatta No.1 Bandar Lampung, mobile : 082183416882 


\section{Pendahuluan}

Peranan jamur dalam kehidupan sangat banyak, baik yang menguntungkan (saprofit) maupun merugikan (patogen). Beberapa jamur jenis tertentu mampu menghasilkan suatu senyawa organik beracun yang disebut mikotoksin (Syarief, 2003).

Salah satu jenis jamur yang bersifat merugikan (patogen) dan menghasilkan aflatoksin yaitu jamur spesies Aspergillus flavus. Aspergillus flavus tersebar luas di dunia. Hal ini disebabkan oleh produksi konidia yang dapat tersebar melalui udara (airborne) dengan mudah. Komposisi atmosfir juga memiliki pengaruh yang besar terhadap pertumbuhan kapang dengan kelembaban sebagai variabel yang paling penting (Hedayati et al., 2007).

Mempelajari sifat-sifat yang dimiliki oleh mikroorganisme seperti jamur, penelitian dapat dilakukan dengan pembiakan melalui media pertumbuhan. Medium merupakan suatu bahan yang terdiri atas campuran zat makanan (nutrient) yang berfungsi sebagai tempat tumbuh mikroba. Suatu media dapat menumbuhkan mikroorganisme dengan baik harus memenuhi persyaratan antara lain: media harus mempunyai $\mathrm{pH}$ yang sesuai, media tidak mengandung zat-zat penghambat, media harus steril, dan media harus mengandung semua nutrisi yang mudah digunakan mikroorganisme (Jutono, 1980).

Nutrisi-nutrisi yang dibutuhkan mikroorganisme untuk pertumbuhan meliputi karbon, nitrogen, unsur non logam seperti sulfur dan fosfor, unsur logam seperti $\mathrm{Ca}, \mathrm{Zn}$, $\mathrm{Na}, \mathrm{K}, \mathrm{Cu}, \mathrm{Mn}, \mathrm{Mg}$, dan $\mathrm{Fe}$, vitamin, air, dan energi (Cappucino, 2014).

Selama ini pernah dilakukan penelitian untuk pertumbuhan jamur Aspergillus flavus dengan menggunakan media SDA (Sabaroud Dextrose Agar) oleh: Gita Andini Putri mengenai gambaran jamur Aspergillus flavus pada saus cabai hasil industri rumahan yang dijual di Pasar Pasir Gintung dan Pasar Smep kota Bandar Lampung (Putri, 2016), dan Mega Ratna Septiana mengenai Identifikasi jamur Aspergillus flavus pada kacang tanah (Arachis hypogaea) yang dijual di Pasar Smep Bandar Lampung (Septiana, 2007). Padahal masih banyak media yang dapat digunakan selain SDA, media agar yang umum digunakan untuk mengisolasi jamur di laboratorium salah satunya adalah PDA (Potato Dextrose Agar ) (Gandjar, 2006).

PDA (Potato Dextrose Agar) adalah media yang umum untuk pertumbuhan jamur di laboratorium karena memilki $\mathrm{pH}$ yang rendah (pH 4,5 sampai 5,6) sehingga menghambat pertumbuhan bakteri yang membutuhkan lingkungan yang netral dengan $\mathrm{pH} 7,0$ dan suhu optimum untuk pertumbuhan antara $25-30^{\circ} \mathrm{C}$ (Cappucino, 2014).

Berdasarkan komposisinya PDA termasuk dalam media semi sintetik karena tersusun atas bahan alami (kentang) dan bahan sintesis (dextrose dan agar). Kentang merupakan sumber karbon (karbohidrat), vitamin dan energi, dextrose sebagai sumber gula dan energi, selain itu komponen agar berfungsi untuk memadatkan medium PDA. Masing-masing dari ketiga komponen tersebut sangat diperlukan bagi pertumbuhan dan perkembangbiakkan mikroorganisme terutama jamur.

Media PDA instan dibuat oleh pabrikpabrik atau perusahaan tertentu sudah dalam bentuk sediaan siap pakai, namun harganya mahal, higroskopis, dan hanya dapat diperoleh pada tempat tertentu. Mahalnya harga media instant yang mencapai Rp 500.000,- hingga Rp 1.500 .000 ,- setiap $500 \mathrm{~g}$ serta melimpahnya sumber alam yang dapat digunakan sebagai media pertumbuhan mikroorganisme mendorong para peneliti untuk menemukan media alternatif dari bahan-bahan yang mudah didapat dan tidak memerlukan biaya yang mahal dan sekaligus dapat mengurangi keseluruhan biaya yang harus dikeluarkan dalam penelitian. Bahan yang digunakan harus mengandung nutrisi yang dibutuhkan untuk pertumbuhan seperti dari bahan yang kaya akan karbohidrat dan protein.

Telah dilakukan penelitian sebelumnya oleh Hany Maryani dari Sekolah Tinggi Analis Kesehatan Bakti Asih mengenai perbandingan pertumbuhan jamur Aspergillus niger pada media PDA (Potato Dextrose Agar) dan media cassava dengan hasil jamur dapat tumbuh pada media sumber karbohidrat cassava (Maryani, 2011). Peneliti lainnya telah berhasil melakukan penelitian dalam menemukan media alternatif untuk pertumbuhan jamur menggunakan berbagai sumber karbohidrat yang berbeda seperti umbi ganyong, umbi gembili dan umbi garut pada jamur Candida albicans dan Aspergillus niger dengan hasil media tersebut dapat digunakan sebagai media alternatif (Aini, 2015).

Komposisi PDA salah satunya adalah ekstrak kentang yang merupakan sumber karbohidrat, sehingga dilakukan alternatif yang komposisinya hampir sama dengan kentang, yakni dengan menggunakan singkong (Manihot 
esculenta Crantz). Umbi singkong merupakan sumber energi yang kaya karbohidrat. Selain umbi akar singkong banyak mengandung glukosa dan dapat dimakan mentah. Rasanya sedikit manis, ada pula yang pahit tergantung pada kandungan racun glukosida yang dapat membentuk asam sianida (Sadjad, 2000).

Singkong (Manihot esculenta Crantz) memiliki jumlah karbohidrat sebanyak 34,00 g sebagai sumber energi, sedangkan kentang memiliki jumlah karbohidrat sebanyak 19,10 g (Hidayat, 2009). Sehingga dapat diketahui bahwa jumlah karbohidrat pada singkong (Manihot esculenta Crantz) lebih banyak daripada kentang. Sumber karbohidrat lain seperti singkong (Manihot esculenta Crantz) juga memiliki berbagai nutrisi cukup sehingga memungkinkan untuk digunakan sebagai media pertumbuhan jamur.

Berdasarkan uraian latar belakang tersebut, maka peneliti tertarik untuk mengadakan penelitian lebih lanjut mengenai "Perbandingan Pertumbuhan Jamur Aspergillus flavus Pada Media PDA (Potato Dextrose Agar) dan Media Alternatif Dari Singkong (Manihot esculenta Crantz)".

\section{Metode}

Penelitian ini bersifat eksperimen, peneliti melakukan kegiatan pengumpulan data berdasarkan hasil pengamatan, kepustakaan, dan dokumentasi dari setiap proses penelitian yang dilakukan. Rancangan penelitian menggunakan Perbandingan Statistik (Statistic Grup Comparison) yaitu membandingkan pertumbuhan jamur Aspergillus flavus pada media PDA dan media alternatif dari singkong yang merupakan variabel bebas. Pertumbuhan jamur Aspergillus flavus me mbandingkan pertumbuhan jamur Aspergillus flavus pada media PDA dan media alternatif dari singkong yang merupakan variabel bebas. Pertumbuhan jamur Aspergillus flavus merupakan variabel terikat dalam penelitian ini.

Penelitian dilaksanakan di Laboratorium Parasitologi Jurusan Analis Kesehatan Politeknik Kesehatan Tanjungkarang. Penelitian dilaksanakan pada bulan Maret-Juni tahun 2017. Subyek penelitian ini adalah media pertumbuhan jamur. Media yang digunakan yaitu media PDA dan media alternatif dari umbi singkong (Manihot esculenta Crantz). Media PDA yang digunakan dalam penelitian ini adalah media PDA instan MERCK dengan nomor katalog 1.10130.0500. Sedangkan media alternatif yang digunakan adalah media yang berasal dari umbi singkong (Manihot esculenta Crantz). Umbi singkong yang dipilih adalah umbi masih segar dengan ciri daging buah berwarna putih bersih, tidak berlendir, dan belum berubah warna menjadi kebiruan atau lebam. Sampel yang digunakan dalam penelitian ini adalah 20 gram umbi singkong (Manihot esculenta Crantz) yang akan dibuat infusa singkong sebagai bahan modifikasi untuk pembuatan media alternatif untuk pertumbuhan jamur Aspergillus flavus.

\section{Hasil}

Berdasarkan hasil pengukuran diameter koloni jamur Aspergillus flavus yang ditanam pada media PDA dan media alternatif dari singkong diperoleh rata-rata diameter koloni Aspergillus flavus sebagai berikut seperti yang tercantum dalam Tabel 1

Tabel 1. Rata-rata diameter koloni jamur Aspergillus flavus

\begin{tabular}{ccc}
\hline \multirow{2}{*}{ Hari } & \multicolumn{2}{c}{$\begin{array}{c}\text { Diameter Koloni Jamur } \\
\text { Aspergillus flavus }(\mathrm{mm})\end{array}$} \\
\cline { 2 - 3 } & $\begin{array}{cc}\text { Media PDA } \\
\text { Media Singkong }\end{array}$ \\
\hline 1 & 6,6 & 6,26 \\
2 & 17,96 & 17,83 \\
3 & 25,23 & 27,66 \\
4 & 32,81 & 37,89 \\
5 & 39,11 & 45,3 \\
6 & 45,14 & 51,21 \\
7 & 49,53 & 56,11 \\
\hline
\end{tabular}

Dari tabel 1 berdasarkan tabel diatas dapat diketahui bahwa terdapat perbedaan pada rata-rata diameter koloni Aspergillus flavus yang ditanam pada media PDA dan media alternatif singkong. Pada tabel terlihat bahwa jamur Aspergillus flavus yang ditanam pada media alternatif singkong lebih besar rata-rata ukuran diameter koloninya dibandingkan yang ditanam pada media PDA.

Data-data diameter pertumbuhan koloni Aspergillus flavus pada media PDA dan media singkong yang diperoleh kemudian dianalisis statistik. Sebelum melakukan uji statistik pada penelitian ini, data variabel dependen dan independen harus dilakukan uji normalitas. Pada hasil uji Shapiro-Wilk menunjukan nilai signifikansi $P$ value $0,472>0,05$. Hasil uji Shapiro-Wilk menunjukkan bahwa sebaran data semua variabel adalah terdistribusi normal ( $\mathrm{p}>$ $0,05)$. 
Selanjutnya dilakukan uji hipotesis untuk mengetahui apakah ada perbedaan yang bermakna signifikan dari diameter pertumbuhan koloni Aspergillus flavus pada media PDA dan media singkong. Peneliti menggunakan uji t test Independen karena data-data yang didapat terdistibusi normal berdasarkan hasil uji normalitas menggunakan uji Shapiro-Wilk.

Tabel 2. Distribusi Rata-rata Diameter Pertumbuhan Koloni Jamur Pada Media PDA dan Media Singkong

\begin{tabular}{ccccccc}
\hline $\begin{array}{c}\text { Diameter } \\
\text { Pertumbuhan } \\
\text { Koloni } \\
\text { Jamur }\end{array}$ & Mean & SD & SE & $\begin{array}{c}\text { P } \\
\text { value }\end{array}$ & N \\
\hline Media PDA & 30,911 & 15,335 & 5,796 & 0,690 & 7 \\
\hline $\begin{array}{c}\text { Media } \\
\text { Singkong }\end{array}$ & 34,592 & 15,219 & 6,886 & & 7 \\
\hline
\end{tabular}

Berdasarkan tabel diatas, rata-rata pertumbuhan diameter koloni pada media PDA adalah $30,911 \mathrm{~mm}$ dengan standar deviasi $15,335 \mathrm{~mm}$, sedangkan untuk media singkong rata-rata diameter koloninya adalah $34,592 \mathrm{~mm}$ dengan standar deviasi $15,219 \mathrm{~mm}$. Hasil uji statistik didapatkan nilai $\mathrm{p}=0,690>0,05$ maka Ho diterima dan $\mathrm{H}_{1}$ ditolak, artinya bahwa tidak ada perbedaan yang signifikan antara rata-rata diamater koloni pertumbuhan Aspergillus flavus pada media PDA dan media singkong.

\section{Pembahasan}

Penelitian ini bertujuan untuk mengetahui perbandingan pertumbuhan jamur Aspergillus flavus dan apakah terdapat perbedaan pertumbuhan jamur Aspergillus flavus menggunakan media PDA dan media singkong. Pengamatan dilakukan sejak hari pertama setelah jamur Aspergillus flavus ditanam pada masing-masing media. Hari pertama pertumbuhan jamur secara makroskopis yaitu terlihat koloni berfilamen, tampak seperti kapas, dan beludru, mula-mula berwarna putih hijau dengan area kuning sulfur pada permukaan koloni diukur pula diameter koloni menggunakan jangka sorong dengan satuan mm (millimeter).

Pertumbuhan diameter koloni jamur Aspergillus flavus pada media PDA dihari ke-1 adalah 6,6 mm. Pada hari ke-2 pertumbuhan diameter koloni jamur mengalami peningkatan yang signifikan yaitu mencapai $17,96 \mathrm{~mm}$. Pada hari ke-3 diameter koloni jamur adalah 25,23 $\mathrm{mm}$. Pada hari ke-4 hingga hari ke-6 pertumbuhan diameter koloni jamur bertambah lebih stabil, yaitu pada hari ke-4 sebesar 32,81 $\mathrm{mm}$, pada hari ke-5 sebesar $39,11 \mathrm{~mm}$, pada hari ke-6 sebesar 45,11 mm. Pada hari ke-7 kecepatan pertumbuhan diameter koloni jamur menurunan yaitu sebesar 49,53 $\mathrm{mm}$.

Pertumbuhan diameter koloni jamur Aspergillus flavus pada media singkong dihari ke-1 adalah 6,26 mm. Pada hari ke-2 hingga hari ke-4 pertumbuhan diameter koloni jamur mengalami peningkatan yang signifikan yaitu mencapai $17,83 \mathrm{~mm}$ pada hari ke-2. Pada hari ke-3 sebesar 27,66 $\mathrm{mm}$ dan pada hari ke-4 sebesar 37,89 mm. Pertambahan ukuran diameter koloni jamur pada hari berikutnya tidak sebesar hari ke-2 hingga ke-4, pada hari ke-5 ukuran diameter koloni sebesar 45,3 mm. Pada hari ke-6 sebesar 51,21 mm dan pada hari ke-7 sebesar $56,11 \mathrm{~mm}$.

Pada hari ke-1, baik media PDA dan media singkong mulai mengalami pertumbuhan. Rata-rata ukuran pertumbuhan diameter koloni pada media PDA 6,6 $\mathrm{mm}$ dan pada media singkong $6,26 \mathrm{~mm}$. Pada hari ke-2, tidak terlihat perbedaan yang signifikan pada rata-rata pertumbuhan diameter koloni, dimana media PDA sebesar $17,96 \mathrm{~mm}$ dan media singkong $17,83 \mathrm{~mm}$. Perbedaan mulai tampak pada hari ke-3 setelah penanaman, dimana terlihat sedikit perbedaan pertumbuhan diameter koloni Aspergillus flavus. Pada media PDA diameter koloninya 25,23 $\mathrm{mm}$ dan pada media singkong sebesar 27,66 mm. Pada hari ke-4, Perbedaan pertumbuhan diameter koloni Aspergillus flavus mulai menunjukan perbedaan dimana diameter koloni pada media PDA 32,81 mm dan media singkong $37,89 \mathrm{~mm}$.

Perbedaan ukuran rata-rata diameter koloni semakin terlihat pada hari Ke-5 hingga hari ke-7. Dimana perbedaan rata-rata diameter sebesar $5 \mathrm{~mm}$ pada masing-masing hari. Ukuran rata-rata diameter koloni Aspergillus flavus pada media PDA di hari ke-5 sebesar 39,11 $\mathrm{mm}$, hari ke-6 sebesar 45,11 mm dan pada hari ke-7 sebesar 49,53 mm. Sedangkan ukuran ratarata diameter koloni Aspergillus flavus pada media singkong di hari ke-5 sebesar 45,30 mm, pada hari ke-6 sebesar 51,21 mm dan pada hari7 sebesar $56,11 \mathrm{~mm}$.

Terlihat bahwa hasil rata-rata ukuran pertumbuhan diameter koloni jamur Aspergillus flavus pada media singkong lebih besar dibandingkan dengan media PDA. Kondisi seperti ini dapat mungkin terjadi disebabkan oleh faktor-faktor yang mempengaruhi pertumbuhan jamur, diantaranya seperti nutrisi, 
media, kondisi fisik seperti suhu, oksigen, $\mathrm{pH}$, lingkungan.

Sumber nutrisi pada media singkong berasal dari air rebusan singkong, dimana diketahui bahwa singkong memiliki kandungan karbohidrat yang lebih tinggi dari kentang namun lebih sedikit kandungan protein. Salah satu nutrisi yang paling dibutuhkan bagi pertumbuhan jamur adalah karbohidrat. Menurut Riyanto (2010), sumber karbon yang umum digunakan oleh jamur adalah karbohidrat (polisakarida, disakarida, monosakarida), asam organik, asam asam amino dan produk natural seperti lignin. Thongklang, dkk (2010) yang menjelaskan bahwa sumber karbon (karbohidrat) adalah nutrisi yang paling penting bagi pertumbuhan jamur dan harus tersedia dalam jumlah yang lebih besar dari nutrisi yang lain. Wulandari, dkk (2012) juga menjelaskan bahwa karbohidrat merupakan komponen esensial semua organisme dan zat yang paling banyak menyusun sel. Fungsi karbohidrat adalah sebagai sumber energi, membentuk struktur sel, struktur penunjang tanaman.

Sumber karbon berguna sebagai energi bagi jamur dalam membentuk sel-sel. Selama proses pertumbuhannya, jamur memerlukan sumber nutrisi dalam bentuk senyawa sederhana agar dapat dengan mudah diserap oleh miselium. Dalam hal ini, jamur akan mengeluarkan enzim untuk menguraikan senyawa kompleks menjadi sederhana, antara lain karbohidrase dan protease. Miselium akan mengeluarkan enzim ekstraseluler ke dalam substrat, kemudian enzim-enzim ini akan mendegradasi senyawa kompleks menjadi lebih sederhana dan miselium akan menyerap senyawa sederhana tersebut untuk sebagai energi untuk pertumbuhan (Chang dan Miles, 2004).

Secara makroskopis, pertumbuhan diameter koloni jamur Aspergillus flavus pada media alternatif dari singkong memang lebih cepat dibandingkan media PDA, tetapi miselium koloni jamur yang tumbuh pada media alternatif dari singkong belum sama seperti pertumbuhan jamur pada media PDA. Area kuning tua pada permukaan jamur yang terlihat jelas pada media PDA, tidak terlihat begitu jelas pada media alternatif dari singkong, selain itu area hijau yang tumbuh pada media alternatif dari singkong tidak setebal area hijau yang tumbuh pada media PDA.

Media singkong memiliki nutrisi yang lebih kompleks sehingga pertumbuhan miselium koloni jamur belum seoptimal media PDA. Hal tersebut dipertegas oleh Gandjar
(2006) menyatakan bahwa kandungan kompleks dalam media menyebabkan jamur uji membutuhkan waktu lebih lama untuk menguraikan menjadi komponen-komponen sederhana yang dapat diserap sel yang digunakan untuk sintesis sel dan energi. Walaupun miselium koloni jamur Aspergillus flavus yang tumbuh pada media alternatif dari singkong tidak sebaik pertumbuhannya pada media PDA, tetapi secara mikroskopis pertumbuhan Aspergillus flavus pada media alternatif dari singkong sama baiknya dengan Aspergillus flavus yang tumbuh pada media PDA, yaitu keduanya memiliki konidiofor yang panjang dan relatif kasar, hifa berseptum, dan koloni kompak. Perbedaan diameter koloni pada media alternatif dipengaruhi oleh kandungan nutrisi (karbohidrat), tingkat kematangan dan kadar serat pada umbi. Umbi yang memiliki kadar serat yang lebih banyak akan sulit jika diekstrak (Koswara,2010).

Faktor lain yang mempengaruhi pertumbuhan jamur adalah faktor pemanasan. Pada proses perebusan menyebabkan komponen dalam air rebusan singkong seperti, karbohidrat, protein, vitamin dan mineral lebih sedikit dibandingkan dengan kandungan PDA, sehingga pertumbuhan jamur yang baik belum terpenuhi. Hal ini terjadi karena proses perebusan yang lama, suhu yang tinggi dan waktu pemanasan yang lama menyebabkan terjadinya perubahan mutu bahan (Lidiasari, E. et al., 2006). Meilisa (2013) menyatakan bahwa dengan adanya pemanasan terjadi penurunan kandungan senyawa seperti protein, vitamin, lemak, dan senyawa lainnya.

Media PDA untuk pertumbuhan jamur Aspergillus flavus menunjukkan hasil lebih baik daripada media singkong karena PDA merupakan salah satu media kultur yang paling umum digunakan sebab formulasinya yang sederhana merupakan media terbaik karena kemampuannya dalam mendukung pertumbuhan pada berbagai jamur (Saha et al,2008).

Dalam penelitian ini ditemukan pertumbuhan koloni yang berada diluar titik awal penanaman yang ditandai dengan adanya pertumbuhan koloni jamur yang bertumpuk pada media pertumbuhan. Hal ini dapat terjadi karena jamur Aspergillus flavus merupakan kelompok jamur udara. Dimana jamur udara merupakan kelompok jamur yang sporanya dapat tersebar di udara bebas. Konidia Aspergillus flavus yang mudah terlepas, berukuran kecil dan ringan sehingga mudah diterbangkan oleh angin. Spora jamur akan 
jatuh dan menempel pada daerah diluar titik penanaman, sehingga menyebabkan koloni jamur tumbuh bertumpuk di dalam media jamur yang sedang dilakukan isolasi dan pengamatan.

Berdasarkan hasil pengamatan dan perhitungan dapat disimpulkan bahwa tidak terdapat perbedaan yang signifikan antara ukuran diameter koloni jamur Aspergillus flavus dan berdasarkan dari perhitungan secara statistik menunjukan tidak ada perbedaan antara media PDA dan media singkong. Dengan demikian, dapat disimpulkan bahwa sebenarnya media singkong merupakan media alternatif yang cukup optimal sebagai pengganti media PDA instan.

\section{Daftar Pustaka}

1. Aini, N 2015. Media Alternatif untuk Pertumbuhan Jamur Menggunakan Sumber Karbohidrat yang Berbeda. Fakultas Keguruan dan Ilmu Pendidikan Universitas Muhammadiyah, Surakarta.

2. Atlas, RM 2010. Handbook of Microbiological Media Fourth Edition. Francis: CRC Press.

3. Cappuccino, J G, Sherman, N 2014. Manual Laboratorium Mikrobiologi. Jakarta: EGC.

4. Ernst, A 2013. Reproduction Aspergillus flavus. Avaible at: http://bioweb.uwlax.edu/bio203/s2013/erns t_ale2/reproduction.html[Accesd February 3, 2017]

5. Gandahusada,dkk. 2006. Parasitologi Kedokteran Edisi Ketiga. FKUI. Jakarta.

6. Gandjar I, Sjamsuridzal W, Oetari A 2006. Mikologi Dasar Dan Terapan . Jakarta, Indonesia: Yayasan Obor Indonesia.

7. Hedayati, et al. 2007. Aspergillus flavus : human pathogen, allergen, and mycotoxin producer. Microbiology.

8. Hidayat B 2009. Karakterisasi tepung ubi kayu modifikasi. Jurnal Teknologi Industri dan Hasil Pertanian. 14:2.

9. Jutono 1980. Pedoman Praktikumn Mikrobiologi Umum. Yogjakarta:Fakultas pertanian UGM.
10. Koswara S. 2010. Teknologi Pengolahan Umbi-Umbian Bagian 7: Pengolahan Umbi Garut.Tropical Plant Curriculum (TPC) Project. Bogor, Indonesia: IPB

11. Lawliet, D. 2016. Media Potato Dextrose Agar. Avaible at: http://teknologilaboratoriummedik.blogspo t.co.id/2016/11/media-potato-dextroseagar-pda.html[Accessed February 4, 2017].

12. Lidiasari, E., et al. 2006. Pengaruh Suhu Pengeringan Tepung Tapai Ubi Kayu Terhadap Mutu Fisik dan Kimia Yang Dihasilkan. Jurnal Teknologi Pertanian. Sumatera Selatan: Universitas Sriwijaya.

13. Maryani, H, 2011, Perbandingan Pertumbuhan Jamur Aspergillus niger Pada Media PDA ( Potato Dextrose Agar) dan Media Cassava, Laporan Tugas Akhir, Sekolah Tinggi Bakti Asih, Bandung.

14. Meilisia, R, 2013, Analisis Pertumbuhan Jamur Aspergillus flavus Pada Modifikasi Media Sabouraud Dextrose Agar (SDA) Dari Tanaman Ubi Jalar (Ipomomea batatas L), Laporan Tugas Akhir, Sekolah Tinggi Bakti Asih, Bandung.

15. Oktari, A, 2007. Penuntun Praktikum Mikologi. Bandung: Akademi Analis Kesehatan Bakti Asih, Laporan Tugas Akhir, Program Studi Analis Kesehatan Sekolah Tinggi Analis Bakti Asih, Bandung.

16. Putri, GA 2016. Gambaran Jamur Aspergillus flavus Pada Saus Cabai Hasil Industri Rumahan Yang Dijual di Pasar Pasir Gintung dan Pasar Smep Kota Bandar Lampung, Karya Tulis Ilmiah, Politeknik Kesehatan, Tanjung Karang.

17. Salim, E 2011. Mengolah Singkong Menjadi Tepung Mocaf Bisnis Produk Alternatif Pengganti Terigu. Yogyakarta. Lily Publisher

18. Septiana, MR 2007. Identifikasi jamur Aspergillus flavus pada kacang tanah (Arachis hypogaea) yang dijual di pasar Smep Bandar Lampung. Karya Tulis Ilmiah, Politeknik Kesehatan, Tanjung Karang. 
19. Soelistijono, 2006. Tanaman Singkong, Jakarta: Penebar Swadaya.

20. Sutanto, dkk. 2008, Parasitologi Kedokteranm Edisi Keempat, Jakarta: Balai Penerbit FKUI.

21. Syarief, R., Ega, L, Nurwitri, CC 2003. Mikotoksin Bahan Pangan. Bogor: IPB Press.

22. Wulandari, E 2012. Limbah Molas: Pemanfaatan sebagai Sumber Karbohidrat untuk Perkembangbiakan Mikroorganisme. ISSN, 2 (5), 565-572. 